\title{
Intervocalic Palatal Glides in Brazilian Portuguese
}

\author{
Thaïs Cristófaro Silva \\ UNIVERSIDADE FEDERAL DE MINAS GERAIS
}

\section{Resumo}

Neste trabalho nós analisamos formas que apresentam glides intervocálicos no português brasileiro, e.g. [méja] 'meia'. Na primeira parte do trabalho nós consideramos as possiveis interpretações para glides intervocálicos de acordo com a Teoria Fonológica de Governo. Após considerarmos o comportamento fonológico de glides intervocálicos nós proporemos que estes são derivados de uma posição nuclear preenchida com uma vogal alta. Nossa análise explica a distribuição de glides intervocálicos em relação ao acento primário no português brasileiro. 


\section{INTRODUCTION ${ }^{1}$}

7 his section has two aims. The first one is to present the morphological structure of nouns and adjectives in Brazilian Portuguese (BP) that is relevant for the analysis we propose later. ${ }^{2}$ Secondly, we identify the environments where intervocalic palatal glides occur as well as the constraints imposed on their distribution. ${ }^{3}$

We assume that the morphological structure of every noun and adjective consists of a stem immediately followed by a nuclear position that corresponds to the gender suffix. The gender suffix may be empty (i.e. not have phonetic content (cf. (1a)) or it may be spelled out by [î,û,a] (cf. (1b-d)). ${ }^{4}$ This is illustrated in (1).

(1)
a. $(\operatorname{pas}+\varnothing)$
[pás]
b. (pas $+\hat{\mathbf{1}})$
[pásî]
c. (pas $+\hat{\mathrm{u}})$
[pásû]
d. (pas +a)
[pása]
'peace'
'pass'
'step'
'raisin'

Let us now consider the distribution of intervocalic glides in BP and the constraint imposed on their distribution. Consider forms in (2).

(2)
a. [sája]
'skirt'
b. [idéja]
'idea'
c. [kúja]
'calabash gourd'
d. [méjû]
'middle'
e. [apójû]
'support' 
Rev. Est. Ling., Belo Horizonte, ano 4, v. 2, p. 5-20, jul./dez. 1995

$\begin{array}{lll}\text { f. } & \text { [gojába] } & \text { 'guava' } \\ \text { g. } & \text { [majó] } & \text { 'bathing suit' } \\ \text { h. } & \text { [bajúka] } & \text { 'small tavern' } \\ \text { i. } & \text { [fejózû] } & \text { 'uglyish' } \\ \text { j. } & \text { [bajonéta] } & \text { 'bayonet' }\end{array}$

In (2a-e) the intervocalic glide occurs posttonically. In $(2 f-j)$ the intervocalic glide occurs in a pretonic position. In (3) we state the constraint imposed on the distribution of intervocalic glides.

(3) Posttonic intervocalic glides require that primary stress be penultimate and fall on the vowel that immediately precedes the glide, e.g. [apójû] 'support'. This constraint excludes forms such as *[ápojû] and *[apójûkụ̂ $/ *$ [gójaba]

The constraint stated in (3) involves the distribution of posttonic intervocalic glides. Concerning the distribution of pretonic intervocalic glides they may immediately precede a primarily stressed vowel, e.g. [gojába] 'guava', or they may occur in a position which is not adjacent to the primarily stressed vowel, e.g. [bajonéta] 'bayonet'.

In the following section we discuss the potential phonological representations for intervocalic glides so that we can determine the more adequate interpretation for analysing them.

\section{THE PHONOLOGICAL REPRESENTATION OF INTERVOCALIC GLIDES}

In this section we will address the potential phonological representations for intervocalic glides in the Government Phonology (GP) framework. Alike other non-linear frameworks (cf. Clements \& Keyser (1983); Goldsmith (1990)) the interpretation of intervocalic glides in GP corresponds to a high vowel being either syllabified in an onset position (flanked between two nuclei) or to a high vowel being syllabified in a nuclear position (as part of the representation of a diphthong). We adopted the GP framework in this paper as a theoretical tool to support our analysis. A comparison of the analysis 
presented here in different frameworks would certainly provide an interesting discussion. However, it would lead us beyond the scope of this article. Let us then consider the potential interpretations for intervocalic glides.

In GP the internal representation of segments consists of one or more elements. ${ }^{5}$ Elements are autonomous, independent, pronounceable units. Segments are charmed or charmless. Positively charmed segments occur in a nuclear head position and negatively charmed segments occur in a non-nuclear position. Charmless or neutrally charmed segments occur either in a nuclear head position or in a non-nuclear position.

The theory assumes that palatal glides represent the cases in which the element $\mathrm{I}^{\circ}$ (that corresponds to the charmless segment 1 ) occurs in a position other than a nuclear head. When the element $I^{\circ}$ occupies a nuclear head position it is manifested as a lax high front vowel, i.e. [i] . When the element $I^{\circ}$ occurs in a position other than a nuclear head it is realized as a palatal glide, i.e. [j]. Below we consider representations where the element $I^{\circ}$ occurs in a position other than a nuclear head so that it is manifested as a palatal glide. ${ }^{6}$

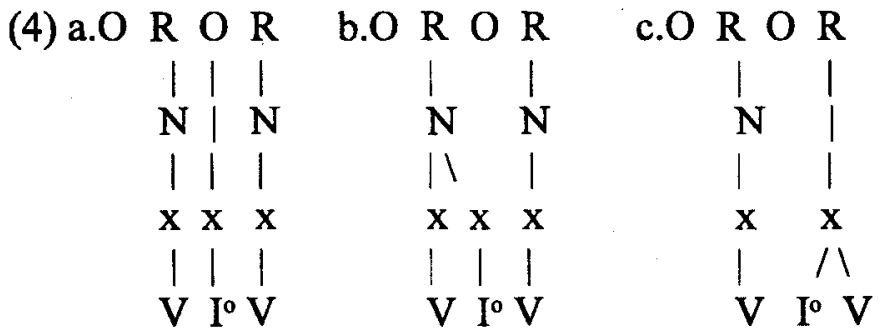

In (4a) the element $I^{\circ}$ occupies an onset position that is flanked between two nuclei. In (4b) the element $\mathrm{I}^{\circ}$ occupies the governed position in the heavy diphthong (the governed position is not a nuclear head position). ${ }^{7}$ This position is immediately followed by a nuclear position that is filled with a vowel. In (4c) we have a nuclear position filled with a vowel which is immediately followed by a light diphthong. ${ }^{8}$ The element $I^{\circ}$ occurs as the left member of the segmental sequence in a light diphthong (which is not a nuclear head position). 
All representations in (4) correspond to vowel-glide-vowel sequences and are therefore potential representations for intervocalic glides.

In the following pages we will consider the representations illustrated in (4) in order to determine how intervocalic glides are phonologically interpreted in BP.

\section{THE PHONOLOGICAL INTERPRETATION OF PALA- TAL GLIDES IN BP}

In this section we determine how intervocalic glides are phonologically interpreted in BP. The simplest hypothesis one can posit is to assume that intervocalic palatal glides represent cases in which the element $\mathrm{I}^{\circ}$ occupies an onset position (cf. (4a)). According to this proposal, a form such as [sája] 'skirt' will have the following representation:

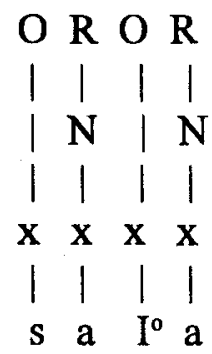

If intervocalic palatal glides represent the element $I^{\circ}$ syllabified in an onset position - as illustrated in (5) - we can expect to find antepenultimate stressed forms which present posttonic intervocalic glides. That is, [ápojû] would hypothetically be a possible form. Thus, in a form such as [ápojû] stress would fall on the third-to-last nuclear position, corresponding to the antepenultimate stress pattern. Forms such as [ézîtû] 'success' and [ápojû] would represent the same stress pattern. In the form [ézîtû] the final onset is filled with the segment t and in the form [ápojû] the final onset is filled with the segment $\hat{\alpha}$.

However, forms such as *[ápojû] do not occur in BP. Whenever an intervocalic glide occurs preceding the gender suffix vowel, i.e. 
the final unstressed vowel of a noun, primary stress falls on the vowel which precedes the glide, i.e. [apójû] 'support'. The lack of forms such as *[ápojû] seems to give us evidence that intervocalic glides do not represent the element $\mathrm{I}^{\circ}$ syllabified in an onset position (cf. (5)). This is because if palatal glides were syllabified in an onset position nothing would prevent stress from falling on the second-to-last nuclear position which precedes the glide, i.e. *[ápojû] should be a possible form.

Nevertheless, BP does not allow palatal consonants to occupy the final onset position in antepenultimate stressed nouns. ${ }^{9}$ That is, forms such as *[mánî $\lambda$ a], * [gálî̃na], *[kúrûža] and *[búlaša] are not possible in BP. Whenever a palatal consonant occupies the final onset position in a noun, primary stress falls on the nuclear position which precedes the palatal consonant, e.g. [maní $a$ a] 'shackle', [galína] 'hen', [kurúža] 'owl', [buláša] 'biscuit'. ${ }^{10}$

We may then propose a constraint according to which palatal consonants cannot occupy the final onset position in antepenultimate stressed nouns in BP. According to this constraint forms such as *[mánî $\lambda a$ ], *[gálîna], *[kúrûža] and *[búlaša] are prevented from occurring. Notice that this constraint may also account for the lack of antepenultimate stressed forms which present posttonic intervocalic glides preceding the final vowel, e.g. "[ápojû]. This is because the palatal glide would correspond to a palatal consonant and therefore it could not occupy the final onset position in antepenultimate stressed nouns.

Therefore, the proposal that palatal glides correspond to the element $I^{\circ}$ syllabified in an onset position - as illustrated in (5) - appears to be correct. The lack of forms which present posttonic intervocalic glides, e.g. *[ápojû], would reflect a general constraint according to which palatal consonants cannot occupy the final onset position in antepenultimate stressed nouns in BP, i.e. *[mánî $\lambda a],{ }^{*}$ [gálîña], *[kúrûža], *[búlaša], *[ápojû] are not possible forms.

On the other hand palatal consonants can occupy the onset position immediately following antepenultimate stressed vowels, e.g. [kãñamû] 'hemp', [méšîkû] 'Mexico' and [frížîû̃] 'frigid'." Therefore, if 
intervocalic glides represent the element $\mathrm{I}^{\circ}$ syllabified in an onset position - as illustrated in (5) - we expect to find antepenultimate stressed forms where the glide immediately follows the primary stressed vowel, i.e. [gójaba] would be a possible form. This is because other palatal consonants can occupy the onset position immediately following antepenultimate stressed vowels, e.g. [frížîû] 'frigid'. Then, nothing would prevent the palatal glide - which would correspond to the element $\mathrm{I}^{\circ}$ syllabified in an onset position - from occupying such a position.

Nevertheless, forms where intervocalic palatal glides occur immediately after an antepenultimate stressed vowel, i.e. * [gójaba], do not occur in BP. Whenever an intervocalic glide occurs preceding the final nuclear position of a noun stem, primary stress falls on the nuclear position which immediately follows the glide, e.g. [gojába] 'guava'. ${ }^{12}$

Thus, the lack of forms where intervocalic glides occur immediately after an antepenultimate stressed vowel, i.e. *[gójaba], provides us with evidence that the phonological representation of intervocalic palatal glides does not correspond to the element $\mathrm{I}^{\circ}$ syllabified in an onset position (cf. (5)). This is because if palatal consonants may occupy the onset position which immediately follows antepenultimate stressed vowels, i.e. [frížîû], nothing would prevent us from finding antepenultimate stressed forms where the intervocalic glide followed antepenultimate stressed vowels. That is, *[gójaba] should be a possible form - which is not the case.

A final argument against assuming that intervocalic glides correspond to the element $\mathrm{I}^{\circ}$ syllabified in an onset position comes from the constraint imposed on the segmental material that may occur in the nuclear head positions that precede and follow intervocalic glides. If we consider intervocalic glides we observe that the vowel (or the nuclear position) that immediately precedes and follows the intervocalic glide cannot be filled with a high front vowel, i.e. *[ijV] and *[Vji]. If we consider palatal consonants we observe that the nuclear position immediately preceding an onset position filled with a palatal consonant may be filled with a high front vowel. Examples 
are: [níñû] 'nest'; [mí $\lambda \hat{u}]$ 'corn'; [lísû] 'rubish' and [hížîdû] 'rigid'. Examples of forms presenting a nuclear position filled with a high front vowel following a palatal consonant are: [kõpañía] 'company'; [koגídû] 'haversted'; [fušíkû] 'gossip' and [mážîkû] 'magician'.

Notice that to account for the lack of forms where intervocalic glides are either preceded or followed by a high front vowel, i.e. *[ijV] and $*[\mathrm{Vji}]$, would lead us to treat the intervocalic glides differently from palatal segments that occupy an onset position. This is because whereas the palatal consonants $\tilde{n}, \lambda, \check{s}, \check{z}$ can be preceded and followed by a high front vowel an intervocalic palatal glide cannot, i.e. *[Vji] and ${ }^{*}[\mathrm{ij} \mathrm{V}]$. The distribution of palatal glides with respect to the adjacent nuclear positions filled with a high front vowel provides us with further evidence that intervocalic glides do not correspond to the element $\mathrm{I}^{\circ}$ syllabified in an onset position (cf. (5)).

If intervocalic palatal glides do not represent the element $\mathrm{I}^{\circ}$ syllabified in an onset position - as illustrated in (5) - we have to determine what the phonological interpretation of palatal glides is. Let us consider the other two phonological representations of intervocalic glides illustrated in (4) which are reproduced below.
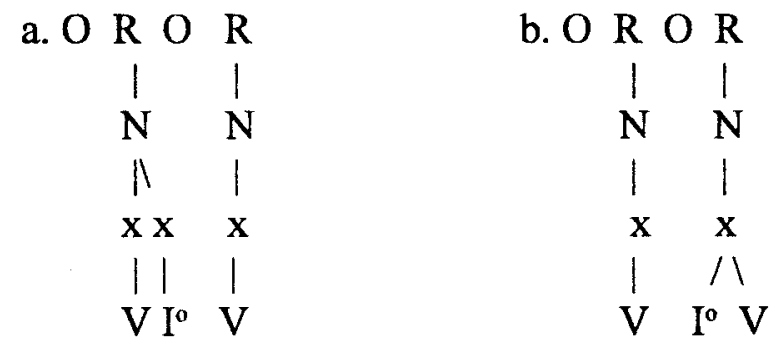

Both representations illustrated in (6) correspond to vowel-glidevowel sequences and are therefore potential representations for intervocalic glides. (6a) represents a heavy diphthong followed by a nuclear position and (6b) corresponds to a nuclear position followed by a light diphthong.

In a more general analysis of BP we propose that both heavy and light diphthongs in BP are derived from a sequence of adjacent nuclear 
positions (cf. CRISTOFARO SILVA (1992b)). That is, glides are derived from a nuclear position filled with either of the simplex charmless segment $\hat{i} / \hat{u}$. Details of this proposal will be presented shortly.

If we assume that either of the representations illustrated in (6) correspond to the structure of vowel-glide-vowel sequences in BP then the lexical representation of vowel-glide-vowel sequences presents a sequence of three consecutive nuclei where the middle nuclear position is filled with the element $I^{\circ}$. This is because according to our proposal heavy and light diphthongs are derived from a sequence of adjacent nuclear positions.

Notice that the proposal that intervocalic palatal glides are derived from a nuclear position filled with the element $\mathrm{I}^{\circ}$ accounts for the distribution of intervocalic glides in relation to the primarily stressed position. We have seen that BP does not allow for antepenultimate stressed forms in which a posttonic palatal glide occurs, i.e. *[ápojû] and *[gójaba] (cf. (3)). The lack of antepenultimate stressed forms presenting posttonic intervocalic glides is accounted for by assuming that the intervocalic glide corresponds to the element $I^{\circ}$ lexically associated to a nuclear head position.

Thus, in a form such as /apoîu/ $\rightarrow$ [apójû] 'support' primary stress falls on the nuclear position which immediately precedes the glide, because otherwise stress would fall on the fourth-to-last nuclear position, i.e. *[ápojû], which is not possible in BP. In a form such as /goîaba/ $\longrightarrow$ [gojába] 'guava' primary stress falls on the nuclear position which immediately follows the glide, because otherwise stress would fall on the fourth-to-last nuclear position, i.e. * [gójaba], which is not possible in BP. We have therefore explained the reasons why the constraint presented in (3) operates in BP.

If the proposal that intervocalic palatal glides are derived from a nuclear position is correct, we can expect to find forms where an intervocalic high vowel bears primary stress, e.g. [baía] 'bay'. Indeed, this is exactly the case. ${ }^{13}$

In the preceding pages we have proposed that intervocalic palatal glides correspond to either the structure of a heavy diphthong followed 
by a nuclear position filled with a vowel or to the structure of a light diphthong preceded by a nuclear position filled with a vowel (cf. (6)). According to our proposal, light and heavy diphthongs are both derived from a sequence of strictly adjacent nuclear positions (cf. CRISTOFARO SILVA (1992b)). Therefore, if intervocalic glides correspond to either structure illustrated in (6) we have to assume that in its lexical representation the palatal glide corresponds to the element $\mathrm{I}^{\circ}$ associated to a nuclear position.

We will now derive the form [sája] 'skirt' assuming that any form which presents intervocalic glides is derived in like manner. Consider the lexical representation of the form [sája] 'skirt' in (7).

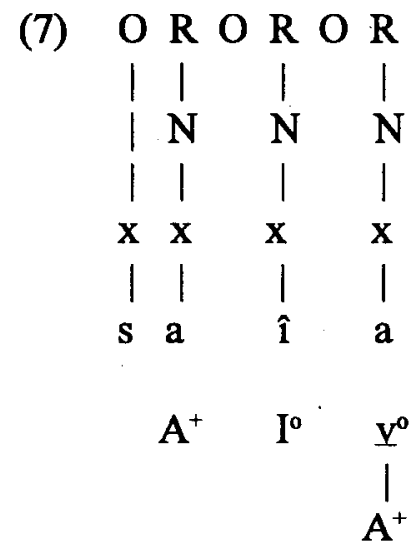

In the lexical representation illustrated in (7) we have a sequence of three consecutive adjacent nuclear positions which are subject to government. Government is a binary relationship between two strictly adjacent skeletal positions (cf. KAYE, LOWENSTAMM \& VERGNAUD $(1985,1990)$, CHARETTE $(1988,1990))$. Given that government is a binary relation, i.e. it involves two skeletal positions, we have to show which two strictly adjacent nuclear positions in (7) interact in a governing relation.

In order for a governing relation to hold, one of the positions must be filled with a segment that has the adequate charm value to govern the segment occurring in the other position. The simplex 
charmless segment $\hat{1}$ (whose internal representation is the element $\mathrm{I}^{\circ}$ ) may be governed by any other nuclear segment of BP. Therefore, an intervocalic nuclear position filled with the simplex charmless segment î may be governed either by the immediately preceding nuclear position - when a left-headed internuclear governing domain is established or by the immediately following nuclear position - when a right-headed internuclear governing domain is established. In (8) we illustrate the derivation of the form [sáj.a] where the glide is understood as belonging to the initial syllable.

(8)

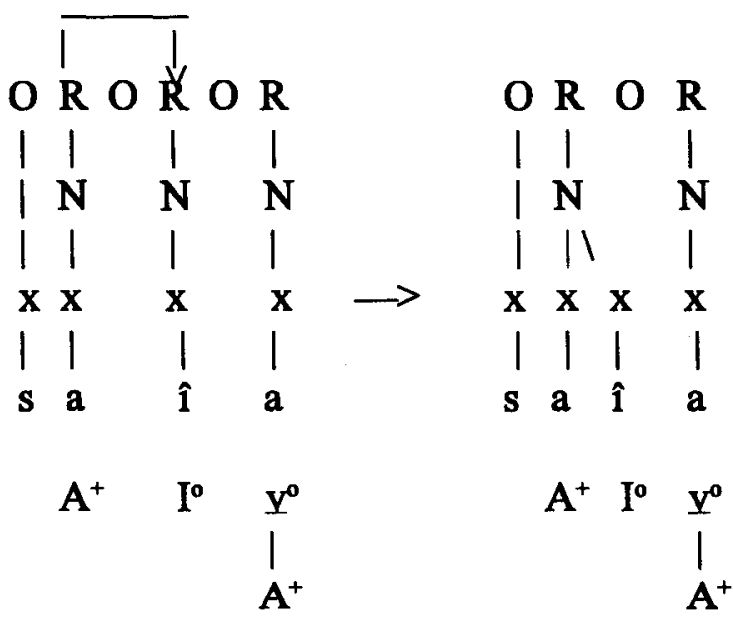

(8) illustrates the establishment of a left-headed internuclear governing domain yielding a heavy diphthong. The heavy diphthong in (8) is immediately followed by a nuclear position filled with the segment [a], so that an intervocalic palatal glide occurs. In (9) we illustrate the derivation of the form [sá.ja] where the glide is understood as belonging to the final syllable. 
(9)

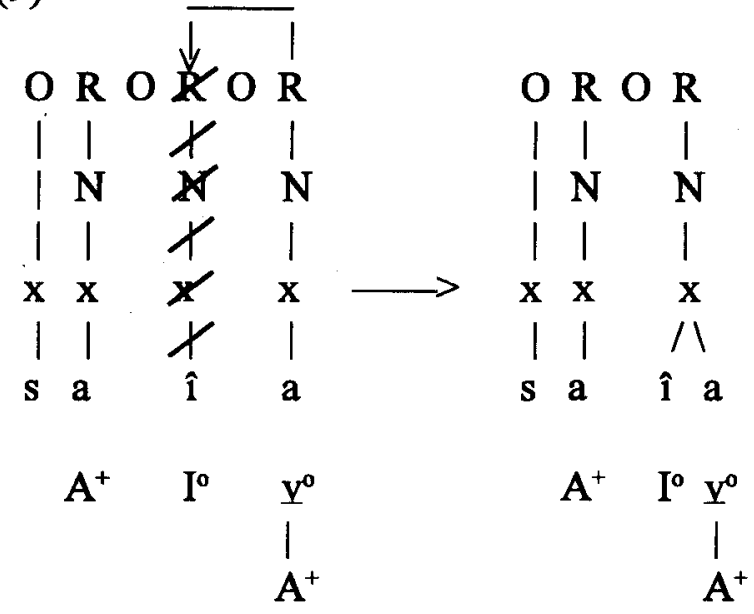

(9) illustrates the establishment of a right-headed internuclear governing relation yielding a light diphthong. The light diphthong in (9) is immediately preceded by a nuclear position filled with the segment [a], so that an intervocalic palatal glide occurs.

In the preceding pages we have seen that intervocalic glides are phonologically interpreted as the element $\mathrm{I}^{\circ}$ associated to a nuclear position where the glide may be interpreted as belonging to the first syllable, i.e. [sáj.a], or belonging to the final syllable, i.e. [sá.ja].

\section{CONCLUSION}

In this paper we have argued that intervocalic palatal glides in BP are derived from a nuclear position. Our analysis accounts for the distribution of intervocalic palatal glides with respect to the primarily stressed vowel in BP. That is, the fact that primary stress will fall either on the vowel that immediately precedes the glide (cf. [apójû] 'support' but *[ápojû]) or on the vowel that immediately follows it (cf. [gojába] 'guava' but *[gójaba]). Our analysis also explains speakers' interpretation of forms presenting intervocalic palatal glides. That is, with the glide either belonging to the first syllable, i.e. [sáj.a], or as it belonging to the final syllable, i.e. [sá.ja]. 


\section{NOTES}

1

This paper is part of a more general analysis of glides in Brazilian Portuguese which was presented in CRISTOFARO SILVA (1992b). A summary of this work is presented in CRISTOFARO SILVA (1994).

2

We restricted our data in this paper to nouns and adjectives because their morphological structure is simpler to be addressed than other grammatical categories. However, the analysis presented here applies to any grammatical category in BP.

3

In our research we found that forms which present intervocalic back glides are all names whose origin comes from Amerindian languages. Considering they are not representative, we did not incorporate them in our data. The data presenting intervocalic back glides we found are: [mawá] 'Mauá (town)', [ananídéwa] 'Ananindéua (town)', [piawí] [pjawi] 'Piauí (state) and [kawé] 'Caue (cement factory)'.

4

$\hat{\imath}$ corresponds to a lax high front vowel, î corresponds to a lax high back vowel.

5

For details on the internal representation of segments cf. KAYE, LOWENSTAMM \& VERGNAUD (1985), YOSHIDA (1991) e HARRIS (1990).

6

Given that in this paper we are analysing intervocalic palatal glides we restrict the representations below to cases where the palatal glide occurs intervocalically.

7

Heavy diphthongs represent what has been referred to in the literature as falling diphthongs. A heavy diphthong represents a governing domain where the leftmost nuclear position is the governor (or the head) and the other nuclear position is the governee (or the complement).

8

A light diphthong corresponds to what the phonological literature has called a rising diphthong. In the representation of a light diphthong a single nuclear position is associated with two segments. The governor segment (or nuclear head) is the rightmost segment in the segmental sequence. For a detailed discussion on light diphthongs see KAYE $(1985,1990 \mathrm{~b})$. 
9

This constraint may be related to the historical development of palatal consonants in Portuguese. A careful discussion of this issue would certainly be an interesting topic for future research in the area of historical linguistics.

10

The strong $\mathbf{R}$ - which is transcribed as [h] - is also not allowed to occur in such a position, i.e. *[sigahu] is not a possible form in BP. Whenever the strong $R$ occupies the final onset position in a noun, primary stress falls on the nuclear position which immediately precedes it, i.e. [sigáhû] 'cigarette'.

11

In our research we have not found forms in which a palatal lateral occupies the onset position immediately following an antepenultimate stressed vowel, e.g.[pá̀asû].

12

Recall that the morphological structure of nouns in BP consists of a stem followed by the gender suffix. Therefore, in a form such as [gojába] 'guava', the final nuclear position of the noun stem is the one which precedes the gender suffix vowel, i.e. the final vowel of the noun.

\section{3}

Except for the form [veíkulû] 'vehicle' we did not find nouns and adjectives in which an intervocalic high vowel bears antepenultimate stress. Cases involving antepenultimate primarily stressed intervocalic vowels were not found in forms without internal morphology, i.e. *[baíaka] or *[baúaka]. In forms presenting the superlative suffix -isîm an antepenultimate stressed front high vowel may be immediately preceded by another vowel, e.g. [feísîmû] 'ugliest'. These forms involve morphological information in their derivations. In verbal forms there are examples where an antepenultimate stressed intervocalic high vowel is preceded by a vowel, e.g. [saiamûs] saiamos '(we) used to go'. When the intervocalic high vowel is not primarily stressed it is realized as a glide, e.g. [sajámûs] saiamos 'let us go'. Forms which present antepenultimate stressed high back vowels immediately preceded by a vowel have not been found, i.e.* [naútîkû] (cf. [náwtîkû] 'nautical').

\section{REFERENCES}

Booij, G. (1989). "On the Representation of Diphthongs in Frisian". Journal of Linguistics. 25. 319-332. 
Cagliari, L.C. (1982). Elementos de Fonética do Português Brasileiro. IEL. UNICAMP. São Paulo.

Câmara (Jr), J.M. (1953). Para o Estudo da Fonêmica Portuguêsa. Organizações Simões. Rio de Janeiro.

Câmara (Jr), J. M. (1970). Estrutura da Língua Portuguêsa. Vozes. Petrópolis. Rio de Janeiro. 14th edition (1984).

Charette, M. (1988). Some Constraints on Governing Relations in Phonology. Ph.D. dissertation, McGill University.

Charette, M. (1990). Conditions on Phonological Government. Cambridge University Press.

Clements, G.N. \& S.J. Keyser (1983). CV Phonology - A Generative Theory of the Syllable. Linguistic Inquiry Monograph. 9. MIT Press.

Cristófaro Silva, T (1990). "Branching Onsets in Brazilian Portuguese". ms. SOAS.

Cristófaro Silva, T. (1992a). "The Phonological Representation of Velar Stop-Glide Sequences". SOAS Working Papers in Linguistics and Phonetics. Number 2. University of London.

Cristófaro Silva, T. (1992b). "Nuclear Phenomena in Brazilian Portuguese”. Ph.D. dissertation. University of London.

Cristófaro Silva, T. (1994). "A silabificação de glides no português brasileiro". Boletim da ABRALIN-Congresso em Salvador.

Goldsmith, J.A. (1990). Autosegmental and Metrical Phonology. Oxford. Blackwell. Harris, J. (1990). "Segmental Complexity and Phonological Government". Phonology Yearbook 7.2. 255-300.

Kaye, J.D. (1985). "On the Syllable Structure of Certain West African Languages". in D. Goyvaerts (ed.), African Linguistics: Essays in Memory of M.W.K. Semikenke, 285-308. Amsterdam, J. Benjamins.

Kaye, J.D. (1989b). Phonology: a Cognitive View. Lawrence Erlbaum Associates, Publishers. N.J.

Kaye, J.D. (1989c). "“"Coda" Licensing".Phonology Yearbook:7.2. 301-330.

Kaye, J.D. (1989d). "On the Interaction of Theories of Lexical Phonology and Theories of Phonological Phenomena". Phonologica 1988.

Kaye, J.D. (ed). (1990b). Phonology Yearbook 7.2.

Kaye, J.D. \& J. Lowenstamm (1984). "De la Syllabicité". in Forme sonore du langage. F. Dell, D. Hirst et J. -R. Vergnaud (eds.). Paris, Hermann.

Kaye, J.D., Lowenstamm, J. \& J-R. Vergnaud (1985). "The Internal Structure of Phonological Elements: A Theory of Charm and Government". Phonology Yearbook 2 (1990). 305-328.

Kaye, J.D., Lowenstamm, J. \& J.-R. Vergnaud. (1990). "Constituent Structure and Government in Phonology". Phonology Yearbook. 7.2. 193-231.

Kaye, J.D. \& J-R Vergnaud (1990). "On the Interaction of Theories of Lexical Phonology and Theories of Phonological Phenomena" Paper presented at GLOW -Cambridge. To appear in Phonologica 1988. Cambridge University 
Press.

Madureira, E.D. (1987). Sobre as CondiçZes da Vocalização da Lateral Palatal no Português. Master Thesis. UFMG. Belo Horizonte.

Steriade, D. (1984). "Glides and Vowels in Romanian". BLS Proceedings. 10. Berkeley University Press. 47-54.

Yoshida, S. (1990). A Government-Based Analysis of the 'Mora' in Japanese. Phonology Yearbook 2.2. 331-335.

Yoshida, S. (1991). Some Aspects on Governing Relations in Japanese Phonology. Ph.D. dissertation. SOAS. London. 